高分子睔文集 (Kobunshi Ronbunshu), Vol. 35, No. 1, pp. $41-47$ (Jan., 1978)

\title{
KBr 単結晶上におけるポリォキシメチレンのエピタキシャル桔晶成長
}

\author{
万木 正*1 · 丸山 裕*2
}

（受付 1977 年 6 月 4 日・秦查終了 1977 年 7 月 21 日）

\begin{abstract}
更旨ボリオキシメチレンの $\mathrm{KBr}$ 単結晶上に拈けるエピタキシャル結晶成辰と生成結晶の䓡処

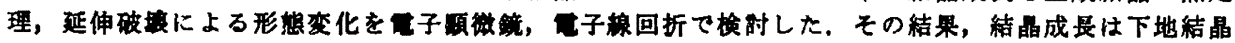

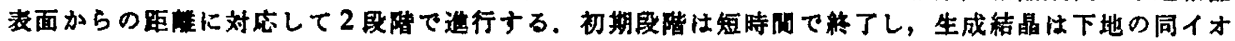

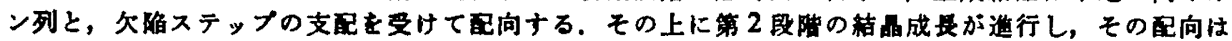
下地結晶と初期殿掿で生成した結晶の影をける。このさいの成長速度は遮く、これる下地からの

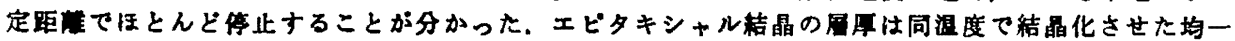

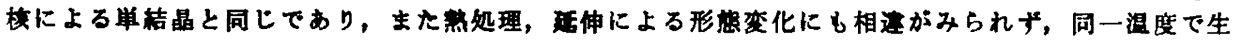

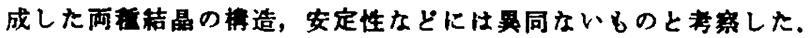

\section{1 解}

取近，高分子の不均一核形成過程を解明するため，高 分子のエビタキシャル結晶化の锶察が行われてい ろ1 〜б). エピタキシャル結晶化は下地結晶棬造との共鳴 効果を持つ結晶成長で, ある種の相互作用のため, 通常 の年件ではほとんど不可能と思われる温度（容解あるい は融解温度に近い)でも容易に短時间で，しかむ下地結 晶格子に支配された特定の配向形態洁晶化する。核形 成に重要な相互作用について種々の要因が検討されてい るが゚)の)，なお明確でない。また生成する結晶の目向形 㑮，大きさなどが著しく生成条件に影電され，棈細な覞 察に等当な試料の調製忙容易でない，著者らは予借実検 により，KBr 単結晶上でのボリオキシメチレンのシク ロヘキサノール溶夜からのエビタキシャル結晶は，ある 温度域で，此較的大きな結晶が再現性よく得られ，また この結晶は下地表面で倒れやすく，〈001〉方向からの锶 察が容易なことを知ったので,この系を実险陚料に使用 し，主として䉓子䫒微鏡覞察と電子線回折法でェピタキ シャル結晶成長過程を検討した。 また下地結晶の支配下 で，高温，短時間に成長するェピタキシャル結晶は，特 定の配向, 形龍だけでなく, 結晶榙造, 久陥の様式, 安 定性などが，通常の均一核形成による単結晶と異なるこ とも考えられるので, 両種結晶の留解挙娌, 延伸による 破裹過程を比渂娭討した。

*1 東京业工大学工学部 (6184 小金井市中町 2-24-16)

*2 セントラル硝子(株)（１01 東京都千代田区神田錦 町 3-7-1)

\section{2 实趺方法}

\section{1 試料}

ボリオキシメチレン (以下 POM と記す) は Derlin 500 XNC 10 を, 下地仙光学研究所提供の $\mathrm{KBr}$ 単結晶 を用いた，溶媒はシクロへキサノールを，市販品を精製 して用いた。

\section{2 エピタキシャル結聂の作成}

POM を溶媒シクロへキサノール中で 30 分間沸滕， 溶解させ，約 $0.01 \%$ 溶液をつくり，これを所定温度に 調節した恒温棈中の試鈋管に移し，10 分後にその中へ 鱀開直後の $\mathrm{KBr}$ を投入してその上に POM を結晶化さ せた．所定時間後に結晶陚料を下地ごと取り出し，すば

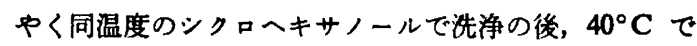
隇圧颙燥した。

\section{3 均一校による巣結品の作成}

エピタキシャル結晶作成と同様, $0.01 \%$ POMーシク 口ヘキサノール溶夜をつくり, $144^{\circ} \mathrm{C}$ の恒温槽中で 24 時間等温結晶化させた。得られた単結晶はェピタキシャ ル結晶との此僌実験に便宜のため, $\mathrm{KBr}$ 結晶上に移し, 洗浄の後暗燥した。

\section{4 結唱试料の繁処理}

$2.2,2.3$ て作成した両結晶試料を下地こと真空封管 し, 所定温度の恒温槽中で 30 分間加鶖した. 処理を終 えた試料は $0^{\circ} \mathrm{C}$ の氷水中に投入し，急冷した。

\section{5 結品试料の延伸}

2.2 の方法で作成したェビタキシャル結晶をマイラー フィルム上に移し, 手動延伸器で延伸した. 


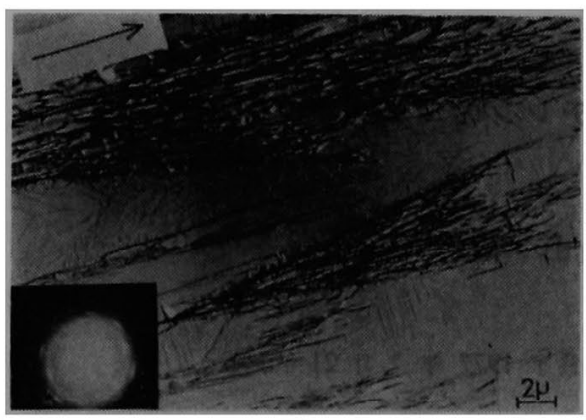

(a)

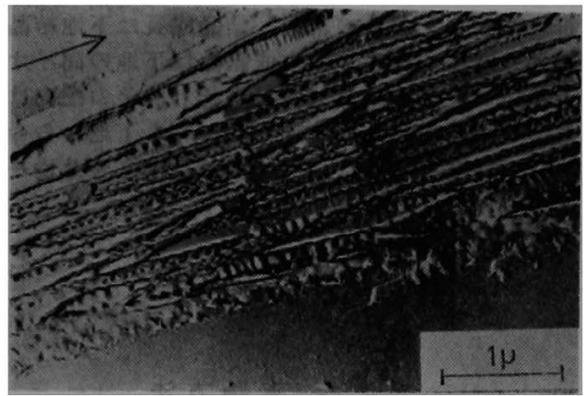

(c)

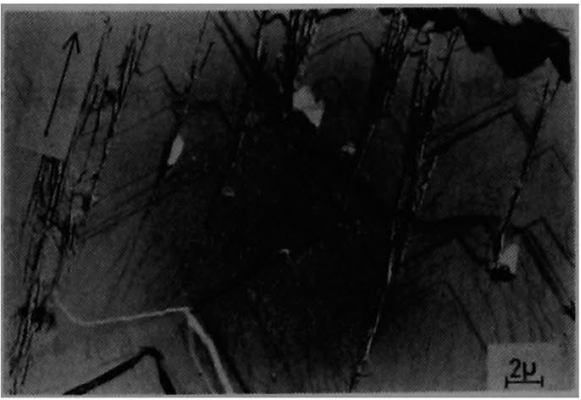

(b)

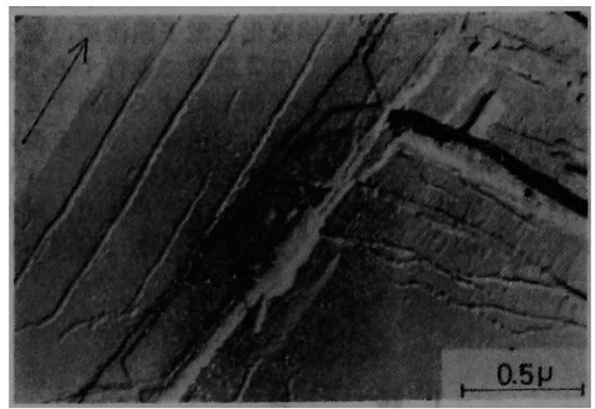

(d)

Fig. 1(a) (d). Electron micrographs of POM epitaxially crystallized on $\mathrm{KBr}$ from cyclohexanol solution at $145^{\circ} \mathrm{C}$ : immersion time, (a), $30 \mathrm{~min}$; (b d), $20 \mathrm{~min}$. Arrows indicate $\langle 110\rangle$ direction of $\mathrm{KBr}$. Shadow angle, $45^{\circ}$. Shown also is the electron diffraction pattern.

\section{6 電子顥微鏡覾察}

結晶およびその䓡処理試料は，白金-カーボン蒸着の 後, 水面に浮へてて下地の $\mathrm{KBr}$ を溶出させ，残った試料 をメッシュにすくい，検鏡試料とした，延伸試料は蒸着 後ボリアクリル酸フィルム上に䔟し，これを水面に浮へ て同様に検镜陚料とした，電子顕微鏡拈よび電子線回折 装盾は(株)日立製作所製 HU 125 DS を使用した。

\section{3 实駼結果およひ考察}

\section{1 エピタキシャル結奛の核形成と成長}

結晶化温度はすべて $145^{\circ} \mathrm{C}$ に一定した，時間を十分 かけ (20 30 分間) 結晶化させたときの,できるだけ種々 の結晶形態が含まれている電子湿微鏡写真を Fig. 1(a, b， c， d) に示した. (a) 中に結晶集合部分の電子線回折

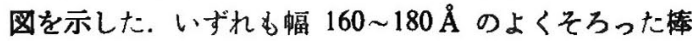
状（実際は板状）に見える小さい結晶と，大きく成長し た結晶，あるいはその集合体が钼察される．後者の結晶 はすぺて下地 $\mathrm{KBr}$ のほぼ〈110〉方向, すなわら同イオ ン列方向に配向している. 回折図からむPOM 分子の主 軸がこの方向に配向していることが分かる.

独立の小さい結晶は下地の欠陥ステッブの影響を受け 配向に乱れを生じている(b). Fig. 2 は結晶化時間を 1

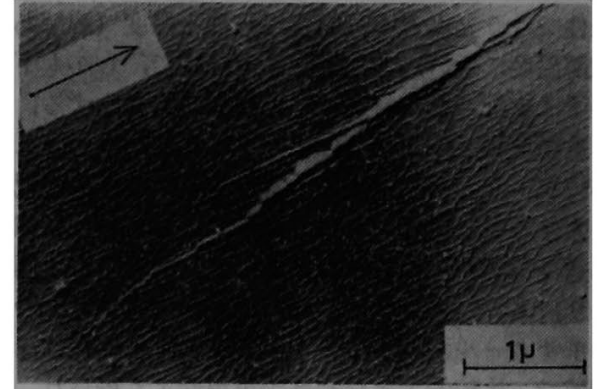

Fig. 2. Electron micrographs of POM epitaxially crystallized on $\mathrm{KBr}$, at $145^{\circ} \mathrm{C}$ for $1 \mathrm{~min}$. Arrow indicates $\langle 110\rangle$ of $\mathrm{KBr}$. Shadow angle, $45^{\circ}$.

分間に短縮したもので，小さい結晶だけから成り，大き さむよくそろっている. この種結晶の析出は極的速 く，1 分間以内に終り，その後は数を增すととむにその 上に大きな結晶が重なって析出し，Fig. 1 のよらな形 態に達したるのと思われる，末分別試料を用いているの で初期に析出する結晶は高分子量の分子から成ることも 考えられるす，10).

なお，20 分以上時間をかけてもはとんど変化がみら 


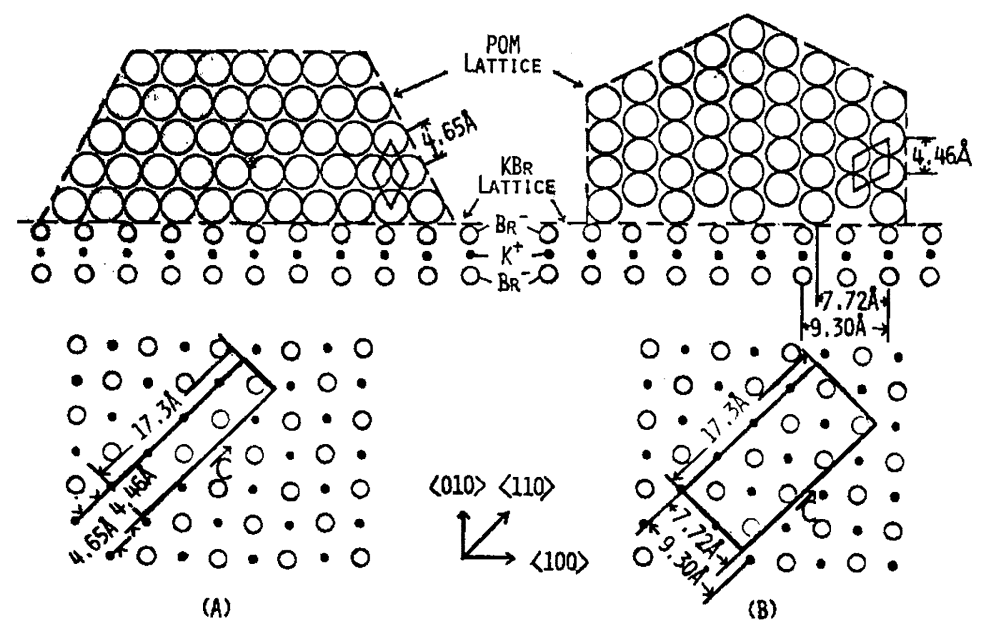

Fig. 3. Two possible manners of epitaxial growth of POM crystals on $\mathrm{KBr}$ : unit cell parameters; POM, $a=b=4.46 \AA, c=17.3 \AA, r=120^{\circ} ; \mathrm{KBr}, a=b=c=4.65 \AA$. Shown also is geometric matching of POM lattice with $\mathrm{KBr}$ ionic arrangement.

れず, 下地に垂直方向の成長は 10 20 分间ですべて䅂 了するものと思われる. エピタキシャル結晶成長が 2 段 階で進行すること，また下地に垂直方向の成長がある距

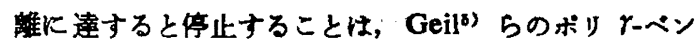
ジル-L-ダルタメートの $\mathrm{NaCl}, \mathrm{KCl}$ 上での実倹結果と同

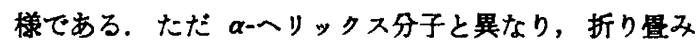
結晶を形成している.

エピタキシャル結晶の下地 (100) 面人倒れた形は,

Fig. 1(c, d) その他以下に示図に見られるよらに， は とんどすべてひずんだ半六角形で, 大きさは下地に垂直 方向では $0.5 \mu \mathrm{m}$ 以下に限られ, 平行方向ではその10 100 倍に達している. また, Fig. 1(c) のよらに1個の 結晶が $0.1 \mu \mathrm{m}$ 程度の周期で波状にゆれることがしばし は見られた。これらは成長の過程に成し，初期段階の 成長では愊 $160 \sim 180 \AA$ の結晶が $\mathrm{KBr}$ 表面の $\langle 110\rangle$,

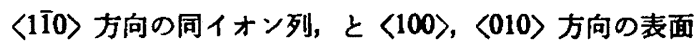
ステッブの影整を受け, $\langle 110\rangle,\langle 11 \overline{1} 0\rangle,\langle 100\rangle,\langle 010\rangle$ 方 向に配向する (Fig. 2). この上に第 2 段階の結晶が析出 するが，第 1 段陼の結晶が久陥ステップの影辢を受けな いときは直線状の形態となる。影稫を受けるときはステ ップ状の形態となる. 初期結晶のステップの周期と後期 の結晶の析出の仕方の組合せにより一定周期の波状形態 をとるむのと思われる。

なおアルカリハライド上での高分子ェピタキシャル結 晶の核形成には，同イオン列，下地表面の欠宿のはかに 两結晶間の格子間隔の一致の影䇾が考えられる。 $\mathrm{Kiss}^{7), 11)}$ らは POM-KCl 系のエビタキシャル結晶に 2 種の核形成棣式を考えているが，これを $\mathrm{KBr}$ 系に適 用すると, Fig. 3 の A, B 型のようになり, 格子間隔

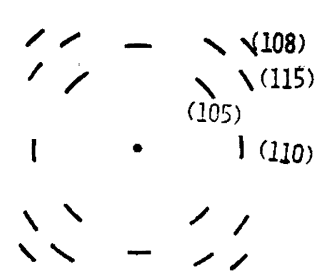

Fig. 4. Electron diffraction pattern of $P O M$ epitaxial crystal. Index asignment of photo. in Fig. 1 (a).

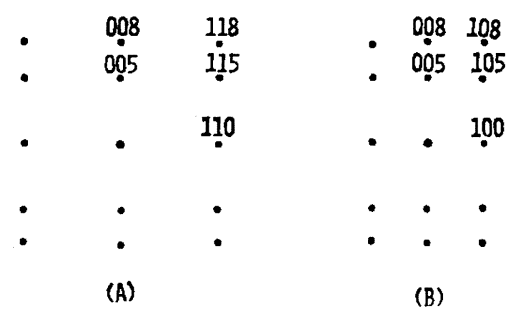

Fig. 5. Reciprocal lattices of two type's epitaxial crystals.

のミスフィット率*8はA型でC軸方向 $-6.9 \%$ ，C軸に 垂直方向 $-4.1 \%$ ，B型でそれぞれ -6.9\%，-17.0\%

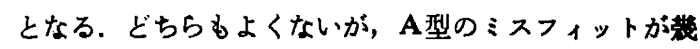
分少ない. Fig. 1 の明視野像ではA型のみより見られ

*8格子間䧣のミスフィット象法次式で表す。 ミス・フィット $(\%)$

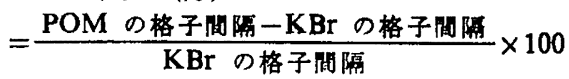




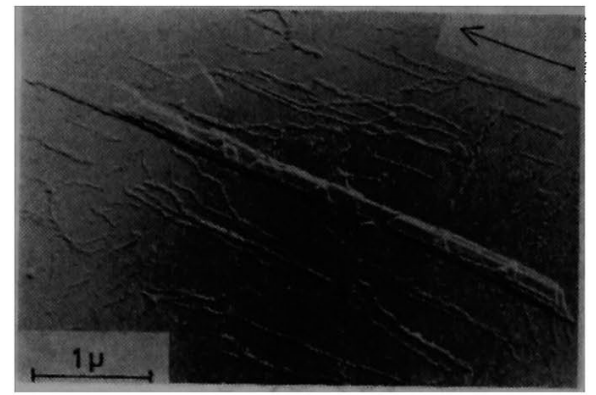

(a)

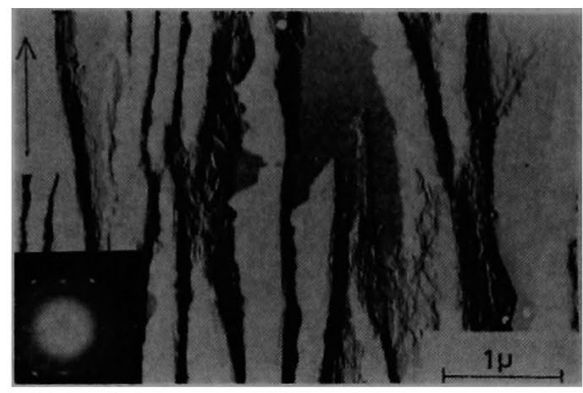

(c)

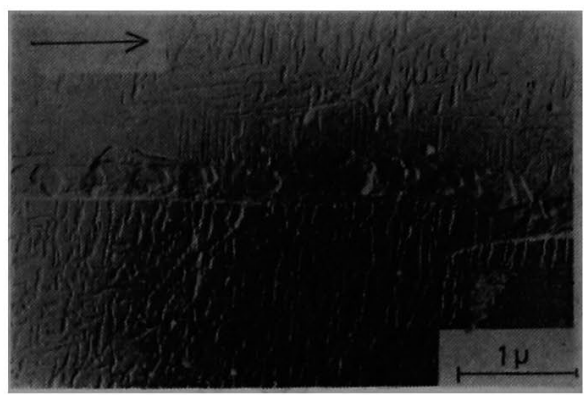

(b)

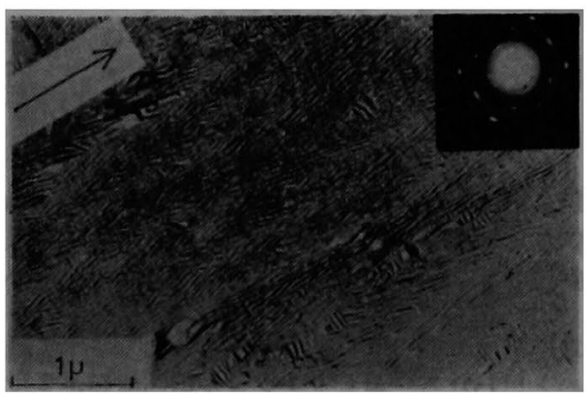

(d)

Fig. 6(a) (d). Electron micrographs of annealed epitaxial crystal of POM on KBr. Arrow indicates $\langle 110\rangle$ of $\mathrm{KBr}$. Shadow angle, $45^{\circ}$. Annealing temp., (a), $155^{\circ} \mathrm{C},(\mathrm{b}), 160^{\circ} \mathrm{C},(\mathrm{c})$, $169^{\circ} \mathrm{C}$, (d), $172^{\circ} \mathrm{C}$.

ないが, 回折図 (Fig. 4) には (105), (110), (115) 回折 か゚強く現れている. 入射電子線に平行に近い面の回折の みが現れるため，両型結晶の逆格子図 (Fig. 5) から分 かるよらにA型では (110)，(115) のみが， B 型では (105) のみが現れることになる. したがって Fig. 1 の 結晶には A， B 両型が混在しているとみなすべきであ ろ. しかし，後述するように下地に接近する部分の結晶 には (105) の回折は現れす゚，A型のみであることが明ら かになり，おそらく初期段階の成長はミスフィットの少 ないA型であり，第 2 段階の成長にはB型も含まれると 考えるべきであろら*4. $\mathrm{NaCl}$ 釆についても実験したが, $\mathrm{KBr}$ 系と同様, 明視野像には $\mathrm{A}$ 型のみが钼察された ${ }^{12}$. 結晶間リンク.Fig. 1 の大きな結晶集合体中に幅 $100 \sim 200 \AA$ の結晶間リンクが多数見られる. Keith ら゙1)はボリエチレンのエビタキシャル結晶に同様のリン クを認め，これを 1 個の分子鎖が複数の結晶の表面で成 長する際の伸ばされた分子鎖，すなわち，結晶間のタイ モレキュールと考えた. しかし,これらリンクは延伸処 理でフィブリル状に引き伸ばされ，垂直方向に折り畺ま れた構造からなることが分かった，おそらく Keith ら

*4 Kiss $ら^{7}$ は KCl 系の実臤でB型の像とA型の回折 を得ている。
のいら成長過程で下地の影䈏を受けこれもェピタキシ ヤル成長してこのよらな構造を形成したと思われる。し かし，下地面から遠く離れた位䈯では伸ばされたタイモ レキュールの存在む可能であろら.

\section{2 第処理による形瑟变化}

エピタキシャル結晶の作成条件はすべて結晶化温度 $145^{\circ} \mathrm{C}$. 結晶化時間 20 分とし, 結晶化温度以上の 145 $\sim 172^{\circ} \mathrm{C}$ の符聿で熱処理した. Fig. 6 に熱処理後の試 料の電子䫒徽鏡写真と回折図を示した（a)の $155^{\circ} \mathrm{C}$ 以 下の処理ではほとんど変化を起こしていない，(b)の $160^{\circ} \mathrm{C}$ 処理で結晶の周辺部が崩れ始め, 中央部は厚化を 起こしている.この傾向は温度の上昇とともに增加して いる. (c) の $169^{\circ} \mathrm{C}$ 処理では, ある部分は融解の後, 下地上に再結晶化し, 新しいェピタキシャル結晶を生成 している. (d) の $172^{\circ} \mathrm{C}$ 処理ではもとの結晶は完全に 融解し，新しいェピタキシャル結晶が全面的に再生して いる. 再生結晶は熱処理温度 (再結晶化温度) の上昇に 伴い㬝厚を增し， $172^{\circ} \mathrm{C}$ では約 $400 \AA$ に達している. (c), (d) に示した回折罒はほとんど同様で，これら結晶 は下地 $\mathrm{KBr}$ の支配を受け，同じ配向を保持している。 ただし，(d) には (110)，(115)，(105) 回折が存在し， 前に述へたA， B 両型結晶が含まれているが，(c) の小 
$\mathrm{KBr}$ 単結晶上におけるポリオキシメチレンのエピタキシャル結晶成辰

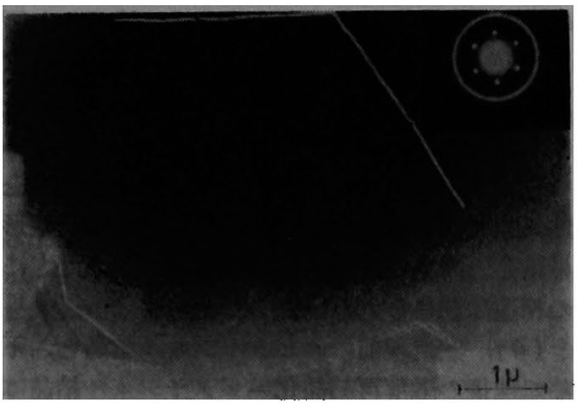

(a)

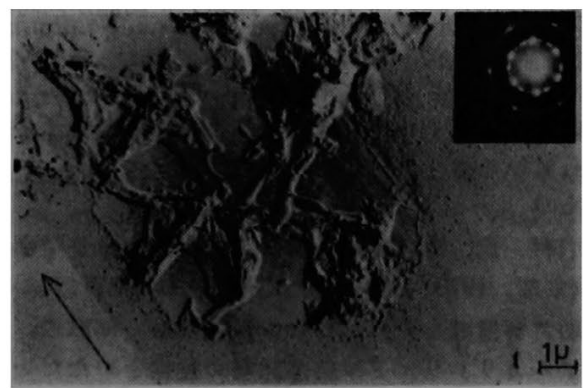

(c)

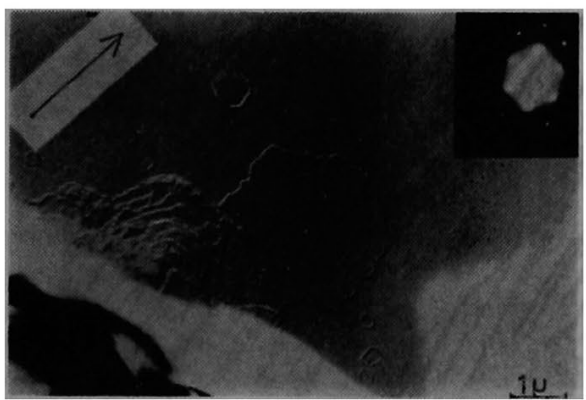

(b)

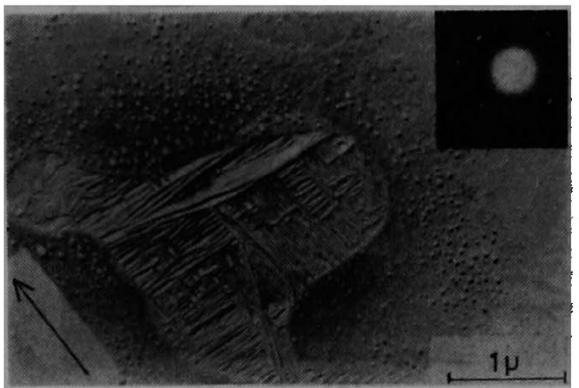

(d)

Fig. 7(a) (d). Electron micrographs of annealed single crystal of $\mathrm{POM}$ on $\mathrm{KBr}$, and corresponding electron diffraction patterns. Arrow indicates $\langle 110\rangle$ of $\mathrm{KBr}$. Shadow angle, $45^{\circ}$. Annealing temp., (a), untreated, (b), $166^{\circ} \mathrm{C}$, and (c), $169^{\circ} \mathrm{C}$, (d), $172^{\circ} \mathrm{C}$.

さい結晶には (115) 回折のみより現れず, 下地に接近し た位置ではA型配置が優先すると思われる。

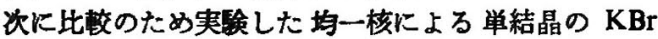
上での熱処理による変化を見る．Fig. 7 に処理前の原 試料および処理後の電子影微鏡写真々回折図を示した. この場合もエピタキシャル結晶と同様 $166^{\circ} \mathrm{C}$ から变形 が始まり，周辺部の崩れ，中央内部の厚化がみられる. $169^{\circ} \mathrm{C}$ 処理では変形が著しく進み，融解した周辺部は その位置でェビタキシャル結晶を再生している．しか し, 強い(100) 回折が認められ，大部分の結晶配向はむ とのままであり，ただし，c軸方向の偏りは大きく，回 折像は多数のスボットの重なりから成っている. (d) の $172^{\circ} \mathrm{C}$ 処理ではほとんど 全面的に尉解, 再結晶化して エビタキシャル結晶を再生している，回折図む完全にェ ピタキシャル結晶を示し，(110)，(115)，(105) 回折が 現れている. 結晶の層厚は約 $400 \AA$ でェピタキシャル 結晶の熱処理の結果と全く同様である.

以上の実験により，熱処理による変化は同一温度で作 成したエピタキシャル結晶と均一核による単結晶との間 に相違は認められず，ほほ同じ温度から変化し始め，同 じ温度で融解の後再結晶化し，同一下地では同一層厚の エピタキシャル結晶を生成することが分かった．立た本
実験に使用した両種結晶の涌厚はいす゚れも 160 1 $80 \AA$ である。従来, エピタキシャル結晶は下地の影敏により， 均一核による単結晶より周厚が大きいといわれている がヷ, そのよらなことは認められず，結晶の厚さは結晶 化温度のみに琢存することが明らかになった．ただし， この実䩡でる分かるよ5に, 融解直後の高温では, 層厚 の叒めて大きい，お゙らく高融点のェビタキシャル結晶 のみが選抧的に生成することは明らかである.

\section{3 延伸による形龍变化}

2.5 の方法でェピタキシャル結晶を延伸したときの電 子影微鏡写真を Fig. 8(a, b) に示した. 結晶の〈110〉

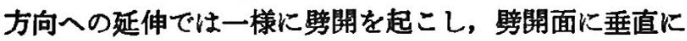
多数のフィプリル束が出ている (a). 高度に延伸すると このフィブリル束は $2 \sim 3 \mu \mathrm{m}$ の長さにまで引き伸ばさ れることが分かった。これに対し〈100〉あるいは〈001〉 方向への延伸では結晶相互の間隙が仏がるだけで晆開し ていない (b). なお延伸前のエビタキシャル結晶にも， 試料作成の過程で延伸されたものと思われるが (110) 面 での䐴開がしばしば認められた，暨開面から〈110〉方向 ヘフィブリルが引き出されるのは, 分子鎖が (100) 面で 折り盢まれているためで,これは Fig. 9 に示した単結 晶の䪪開と全く同じである. 


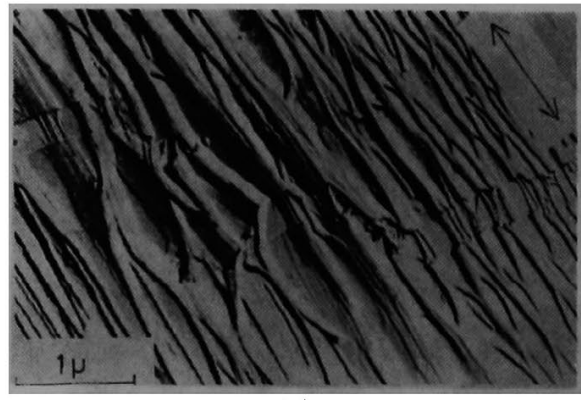

(a)

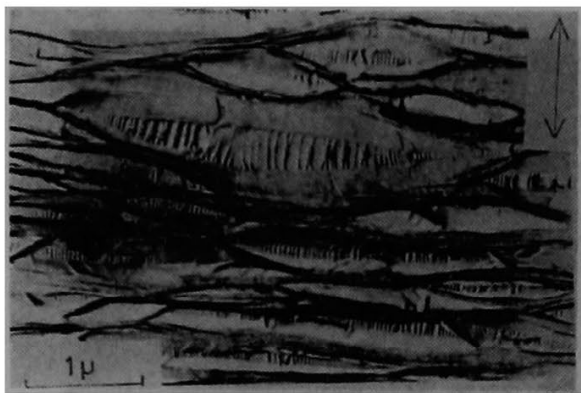

(b)

Fig. 8(a), (b). Electron micrographs of drawn epitaxial crystals of POM. Arrows indicate direction of draw. Shadow angle, $45^{\circ}$.

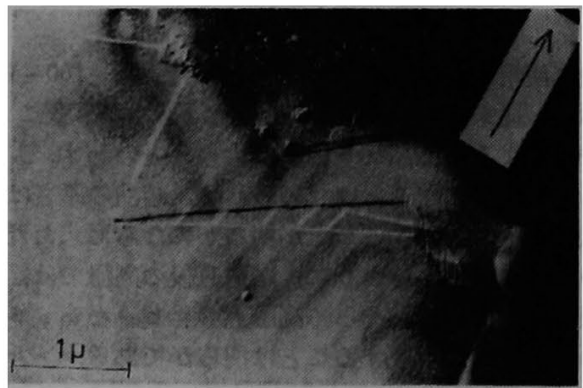

Fig. 9. Electron micrograph of the cleavage of POM single crystal. Arrow indicates direction $\langle 110\rangle$ of the crystal. Shadow angle, $45^{\circ}$.

\section{4 繶 括}

$\mathrm{POM}-\mathrm{KBr}$ 采のエピタキシャル結晶の成長拈よびそ の熟処理, 延伸による形佂変化を追求し，次の結果を得 た.

(1) POM は $\mathrm{KBr}$ 辟開面で2段階のエピタキシャ 几結晶成長する．第 1 段階の成長は短時間で終り， $\mathrm{KBr}$ の同イオン列の支配と表面の欠陥ステップの影響を受け $\langle 110\rangle$ ，〈100〉方向に配向寸る. その上に 第 2 段階の成 長を起こし大きな結晶が析出する，その際は第 1 段階の 結晶配向の影響を受け種々の配向形態をとる．第 2 段階
の成長も結晶の䅉厚がある大きさに洼すると停止する。

”(2) エピタキシャル結晶集合体中には多数の結晶間 リンクが認められた。下地に近いるのは折り眐み構造を もち、これもエピタキシャル結晶と考えられる.

(3) エピタキシャル結晶を結晶化温度以上の温度で 熱処理すると，同温度で結晶化させた均一核形成による 単結晶と同様の変化を示し，畨厚，融点などに両結晶間 の相连は認められない。

（4）熱処理前のエピタキシャル結晶と，下地上での 熱処理後の融解再結晶化エピタキシャル結晶は同一の電 子線回折を示し，(100) 面が下地に平行に配向する結晶 とこれが $c$ 軸の周りに $30^{\circ}$ 回転した結晶が同時に存在す ๖.

（5）エピタキシャル結晶は延伸破壤により〈110〉方 向にフィプリルが引き出され (100) 面に分子が折り䡒ま れていることが確かめられた.

付 钎 本研究の一部江第 22 回高分子学会年次大会 (京都，1973）で発表した。最後に本研究に対し有益な御 助吉御指導をいただいた本学坂奥吾一郎教投ならびに フルカリハライド単結晶試料の提供をいただいた東京数

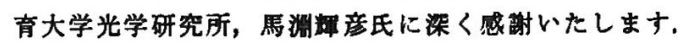

\section{文嗝}

1) J. Willems, T. Willems, Experimentia, 13, 465 (1957).

2) E.W. Fischer, Discus. Faraday Soc., 25, 204 (1957).

3) J. A. Koutsky, A. G. Walton, E. Baer, J. Polym. Sci., Part A-2, 4, 611 (1966), Part B, 5, 177 (1967), 185 (1967).

4) S.H. Carr, A.G. Walton, E. Baer, Biopolymers, 6, 469 (1968).

5) F. Rybnikar, P.H. Geil, Makromol. Chem., 158, 39 (1972); J. Polym. Sci., Part A-2, 10, 961 (1972).

6) 小林惠之助, 高霓利襀, 科学, 34, 325 (1967).

7) K. Kiss, S.H. Carr, A.G. Walton, E. Baer, J. Polym. Sci., Part B, 5, 1087 (1967).

8) K.A. Maurity, E. Baer, A.J. Hopfinger, $J$. Polym. Sci., Polym. Phys. Ed., Part B, 11, 2185 (1973); 13, 789 (1975).

9) S. Wellinghoff, F. Rybnikar, E. Baer, $J$. Macromol. Sci., Phys., B10, 1 (1974).

10) S.H. Carr, J. Polym. Sci., Part A-2, 10, 755 (1972).

11) K. Kiss, S.H. Carr, A.G. Walton, E. Baer, J. Polym. Sci., B5, 177 (1967).

12）丸山裕，並本 党，万木 正，第 22 回高分 子学会年次大会要旨集, 1, 213 (1973).

13) H.D. Keith, F.J. Padden, Jr., R.G. Vadimsky, J. Appl. Phys., 37, 4027 (1966); 42, 4585 (1971). 
$\mathrm{KBr}$ 結晶上に扔けるポリオキシタチレンのエピタキシャル結晶成長

\section{Epitaxial Crystallization of Poly(oxymethylene) on KBr Single Crystal}

\section{Tadashi YURugi*1 and Yutaka MAruYama*2}

*1 Faculty of Technology, Tokyo University of Agriculture and Technology (24-16, Naka-cho 2-chome, Koganei 184)

${ }^{* 2}$ Central Glass Co. Lid., (7-1, Kanda Nishikicho 3-chome, Chiyoda-ku, Tokyo 101)

The isothermal epitaxial crystallization of poly(oxymethylene) on cleaved surface of $\mathrm{KBr}$ single crystal was studied by means of electron microscopy and electron diffraction. It was found that the epitaxial growth proceeds through two processes distinguishable by distance from the substrate surface. The first process proceeds very rapidly and the crystals formed are aligned in both $\langle 110\rangle$ and $\langle 100\rangle$ directions of $\mathrm{KBr}$. The secondary process proceeds slowly and alignments of crystals overgrown are affected by the orientation of the crystals deposited during the first process, as well as by the lattice structure of the substrate, resulting in the aggregated large crystals of somewhat complicated shapes.

Lamellae-thickness, melting behavior and deforming appearance were observed by stretching the epitaxial crystals and compared to those of a self-seeded single crystal crystallized at the same temperature, and appreciable difference was never found in every respect. This result suggests that there is no difference between the crystalline structures of two types.

KEY WORDS Poly(oxymethylene) / Epitaxial Crystallization / Electron Diffraction / Lattice Matching /

Lamellae-thickness / Annealed Epitaxial Crystal /

(Received June 4, 1977: Accepted July 21, 1977)

[Kobunshi Ronbunshu, 35(1), $41-47$ (1978)] 